\title{
Abnormal gonads in the Antarctic toothfish (Dissostichus mawsoni Norman, 1937 [Perciformes: Nototheniidae]): the first record and histological description
}

\author{
Kristina A. Zhukova (iD) ${ }^{a}$, Ilya I. Gordeev (iD ${ }^{b, c}$ \& Elena N. Kuznetsova (iD ${ }^{a}$

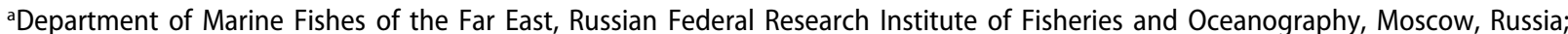 \\ bPacific Salmons Department, Russian Federal Research Institute of Fisheries and Oceanography, Moscow, Russia; 'Department of \\ Invertebrate Zoology, Faculty of Biology, Lomonosov Moscow State University, Moscow, Russia
}

\section{ABSTRACT}

This paper describes the morphology and histology of abnormal gonads in Antarctic toothfish (Dissostichus mawsoni) and the possibility of intersexuality and senescence of some individuals. Two old (approximately 25 years) and large $(184-185 \mathrm{~cm})$ specimens with abnormal gonads were caught in the Antarctic during commercial fishing for toothfish and studied using histological methods. Although $D$. mawsoni is well-known and extensively studied, this is the first study dealing with abnormal gonads in the species. The histological analysis revealed that the gonads of the first specimen contained both male and female germ cells (ovotestis), the testicular and ovarian tissues being separated by a thick layer of connective tissue. The female portion was composed of secondary vitellogenic oocytes, primary vitellogenic, cortical alveolar and primary growth oocytes, while the testes contained cysts of spermatogonia and primary spermatocyte. The gonads of the second specimen were small, filiform and showed massive growth of the connective tissue, which occupied almost the entire gonad; a few spermatogonia without visible cysts were found. This study extends our understanding of sexual development in Antarctic toothfish, documenting the possibility of long-term interruptions in the reproductive cycle of this species.

\section{KEYWORDS}

Cod icefish; histology; intersex; senescence; reproduction; CCAMLR

ABBREVIATIONS

BW: body weight; $\mathrm{BW}_{1}$ : eviscerated weight; CCAMLR: Convention of the Conservation of Antarctic Marine Living Resources; GSI: gonadosomatic index; GW: gonad weight; HSI: hepatosomatic index; HW: liver weight; TL: total body length

\section{Introduction}

The Antarctic toothfish (Dissostichus mawsoni Norman, 1937) and its congener, the Patagonian toothfish (Dissostichus eleginoides Smitt, 1898), are among the main target species of exploratory fishing in the CCAMLR area, which includes the whole Antarctic and most of the sub-Antarctic regions.

Though D. mawsoni is well-known and extensively studied, timing and location of spawning are still uncertain. It has been hypothesised that within the CCAMLR Subareas 88.1 and 88.2 (the Ross and Amundsen seas, respectively), $D$. mawsoni spawn mainly on the oceanic ridges and banks of the Pacific-Antarctic ridge north-east of the Ross Sea (Hanchet et al. 2008). Spawning likely takes place during the austral winter and spring (Yukhov 1982; Eastman \& DeVries 2000; Hanchet et al. 2008). A recent genetic study (Mugue et al. 2014) found no significant genetic differences around the Antarctic, and low genetic diversity and temporal stability in Antarctic toothfish from the near-continental seas of Antarctica. Based on tagging studies, D. mawsoni generally did not migrate more than $100 \mathrm{~km}$, except for a single record of a tagged fish recaptured $2300 \mathrm{~km}$ far from the release site (Dunn et al. 2007; Hanchet et al. 2008).
Several studies have examined the reproductive biology of both Antarctic and Patagonian toothfish (Yukhov 1982; Everson \& Murray 1999; Eastman \& DeVries 2000; Prutko \& Lisovenko 2005; Fenaughty 2006; Piyanova 2008; Piyanova \& Kokorin 2010; Parker \& Grimes 2010; Hanchet et al. 2008, Hanchet et al. 2015). The Antarctic toothfish is an iteroparous, gonochoristic species with a prolonged oogenesis, characterized by an oocyte development process of at least two years, and spermatogenesis lasting one year (Eastman \& DeVries 2000; Piyanova \& Petrov 2009; Parker \& Grimes 2010).

Anomalies of gonad development usually cause lower fecundity or skipped spawning (Rideout et al. 2005). Reports of gonad anomalies in the Antarctic toothfish are very scarce. Some authors described atretic processes in the ovaries of post-spawning females as a normal rearrangement of gonad tissues (Eastman \& DeVries 2000; Livingston \& Grimes 2005; Piyanova \& Petrov 2009; Parker \& Grimes 2010). An abnormal fusion of the renal tissue with the generative portion was recorded in the testis of an Antarctic toothfish (Piyanova \& Kokorin 2010), while Parker \& Grimes (2010) reported skipped spawning in some females. 
This paper describes the morphology and histology of abnormal gonads in Antarctic toothfish and the possibility of intersexuality and senescence in some individuals.

\section{Materials and methods}

Two specimens with abnormal gonads were caught in the CCAMLR Subarea 88.1 during commercial fishing for toothfish using a bottom longline (Petrov et al. 2014). TL, $\mathrm{BW}, \mathrm{BW}_{1}$, GW and HW of 3382 specimens were measured. The age of the fish were calculated by their length, according to Kuznetsova et al. (2012). GSI and HSI were calculated as percentage of GW and HW to BW. Gonad stage of maturity was macroscopically assessed on board according to methods in the Scientific observers manual (CCAMLR 2011).

The first specimen of D. mawsoni (TL $184 \mathrm{~cm}$; BW $58.5 \mathrm{~kg}$ ) was caught on 6 December 2014 in the Ross Sea by the FV Yantar $-31\left(65^{\circ} 14.8^{\prime} \mathrm{S} \& 178^{\circ} 33.1^{\prime} \mathrm{W}, 1822 \mathrm{~m}\right.$ depth). The second specimen (TL $185 \mathrm{~cm}$; BW $91.8 \mathrm{~kg}$ ) was caught in the Ross Sea by the FV Palmer on 11 January 2015 ( $72^{\circ} 54.6^{\prime} \mathrm{S} \& 177^{\circ} 19.7^{\prime} \mathrm{W}, 1221 \mathrm{~m}$ depth).

For the histological analysis, gonads were fixed in $4 \%$ formaldehyde solution. The samples were then dehydrated, cleared with xylol, embedded in paraffin, sectioned at 3-5 $\mu \mathrm{m}$ and stained with hematoxylin and Ehrlich's eosin. Histological sections were viewed under a light microscope (Olympus BX45) equipped with a digital camera (Leica DC 100), and staged according to methods described by Brown-Peterson et al. (2011).

\section{Results}

The two specimens with abnormal gonads were large (184 and $185 \mathrm{~cm} \mathrm{TL}$ ) and old (25 years) enough to be considered sexually mature and to have previously spawned.

The HSI of the first specimen $(2.82 \%)$ was close to that observed for other fishes with ovaries in the developing phase (HSI $2.35 \% \pm 0.13$ SD; GSI $2.93 \%$ $\pm 0.07 \mathrm{SD}$ ), but the GSI was slightly lower (1.42\%).

Gonads were large in size with a macroscopic abnormal appearance. The right ovary and the anterior portion of the left ovary were normal, while the posterior portion looked like testes (Fig. 1a).

Histologically, the gonads consisted of both male and female germ cells (Fig. 2). The testicular and ovarian tissues were separated by a thick layer of connective tissue (Fig. 2c). Male and female germ cells were well separated from each other, so this gonad displayed a delimited type of ovotestis, according to Sadovy \& Shapiro (1987).

The female portion was in the developing phase, consisting of secondary vitellogenic oocytes, primary vitellogenic, cortical alveolar and primary growth oocytes. Normally developing oocytes were found in the central and peripheral portions of the testis, and there were no differences in oocyte condition and composition between the left and right ovaries. Oocyte resorption was located in the ovigerous lamellae of the left ovary, proximal to the testis. Atretic follicles were composed of a resorbed zona radiata surrounded by the granulosa cells, and a thin theca layer (i.e., beta-stage atresia [Hunter \& Macewicz 1985]). The testis was in the early developing subphase, containing cysts with spermatogonia and primary spermatocytes, as well as sparse cystic membrane disintegration and connective tissue proliferation (Fig. 2d).

The HSI of the second specimen (2.85\%) was higher than that of all other males caught (HSI $1.87 \% \pm 0.7 \mathrm{SD}$; average GSI $1.16 \%$ ), while the GSI was the lowest $(0.15 \%)$. The gonads appeared macroscopically normal, although very small for such a big fish, with the appearance of an immature testis (Fig. 1b).

The histological analysis revealed massive growth of the connective tissue which occupied almost the whole gonad, with many narrow lumina. Rare spermatogonia without visible cysts were noted among the thick layers of connective tissue (Fig. 3a). For comparison, in the normal testes of a male caught in the same region (TL $123 \mathrm{~cm}$,
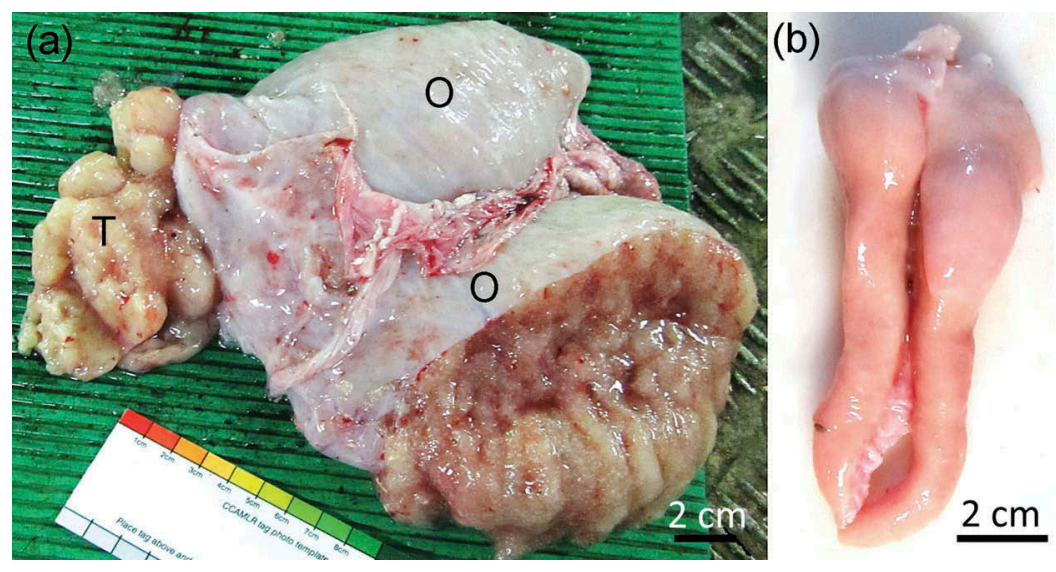

Figure 1. Antarctic toothfish abnormal gonads from (a) the first, bisexual specimen, with the ovaries (O) and testis (T) indicated, and (b) the second specimen, with filiform gonads. 

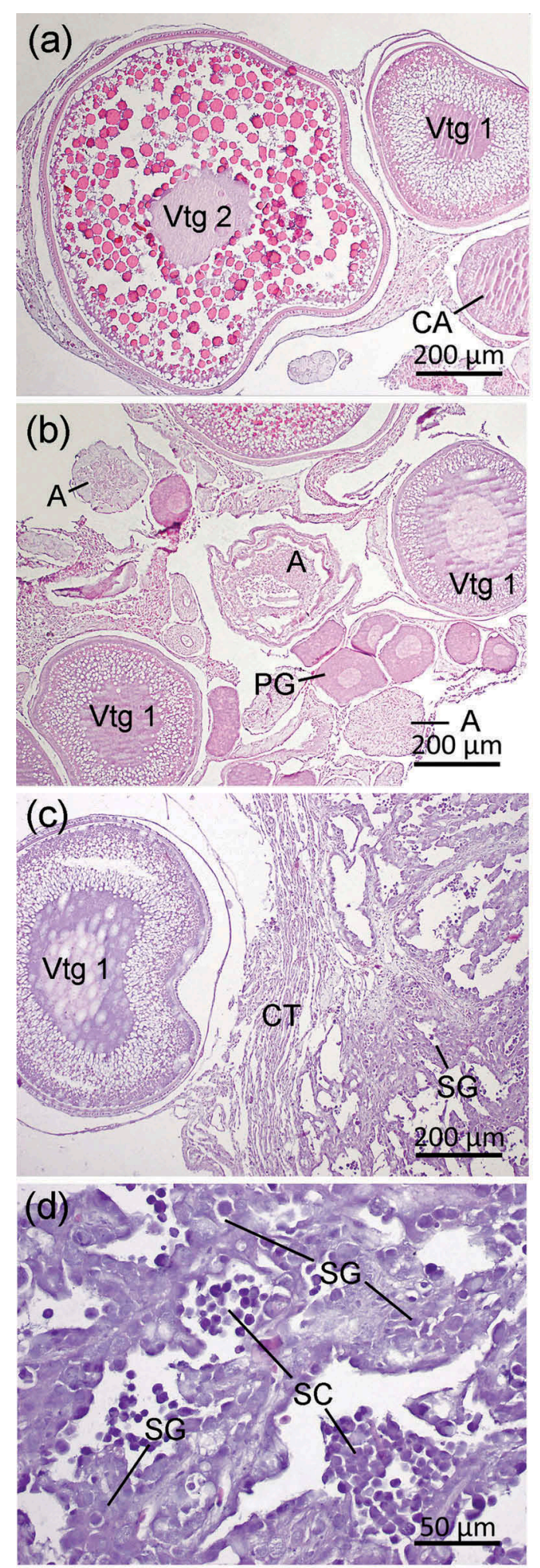

Figure 2. Histological characteristics of the bisexual gonads of the first specimen: (a) ovarian portion; (b) oocyte resorption area near testicular and ovarian tissue junctions; (c) testicular and ovarian tissue junctions; (d) testicular portion of ovotestis. Abbreviations: CT—connective tissue, PG—primary growth, CA - cortical alveolar, Vtg1—-primary and Vtg2-secondary vitellogenic oocytes, A—atretic follicles, SG—spermatogonia, SC—primary spermatocyte.
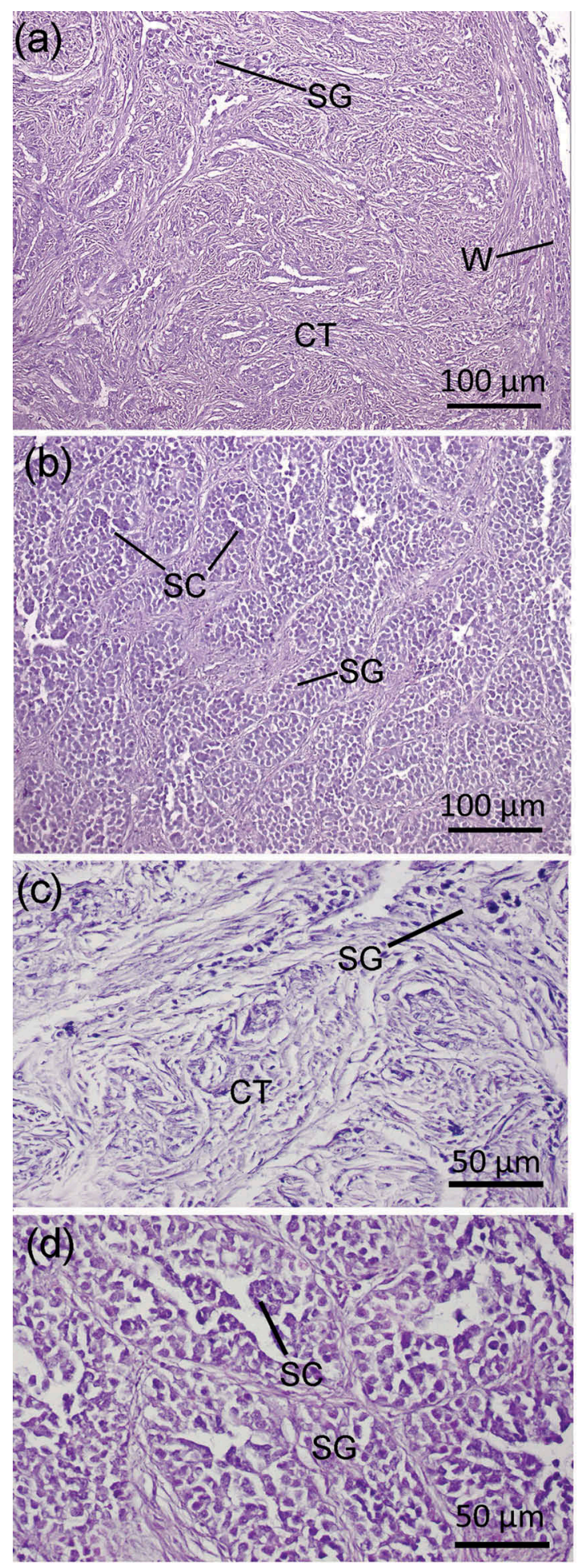

Figure 3. Histological characteristics of (a) and (c) the filiform gonads of the second specimen and (b) and (d) the normal testes of Antarctic toothfish. Abbreviations: CT-connective tissue, SGspermatogonia, SC-primary spermatocyte, W-wall of the gonad.

BW $22.4 \mathrm{~kg}$, GSI 0.35\%), cysts with spermatogonia predominated, while rare cysts with early spermatocytes were also noted (Fig. 3b). 


\section{Discussion}

As the studied specimens with abnormal gonads were rather large and old compared to size and age at sexual maturity of D. mawsoni reported elsewhere (Parker \& Grimes 2010), it is likely that they have already spawned several times in the past, assuming they had normal gonads. In both cases, gonad anomalies may be related to fish senescence.

TL and weight of fish with abnormal gonads were greater than in fish with normal gonads. Greater length, weight and HSI may be due to the fact that the second sample did not spend energy on the development of gametes and spawning, and could develop somatic growth more (McBride et al. 2015).

Most representatives of the family Nototheniidae are gonochoric, as individuals develop into males or females at birth and do not change sex throughout their life span (e.g., Ghigliotti et al. 2016). Protandry has been recorded among the sub-Antarctic notothenid Eleginops maclovinus (Calvo et al. 1992), but their gonads differ from the Antarctic toothfish ovotestis: oogonia and primary growth oocytes were found in cysts, with male germ cells belonging to the undelimited type (sensu Sadovy \& Shapiro 1987). In these gonads, there was progressive degeneration of male germinal tissue and development of the female counterparts (Calvo et al. 1992). A case of intersex (Yamamoto 1969) or abnormal hermaphrodism (Atz 1964) perhaps occurred in the Antarctic toothfish with bisexual gonads. Such unusual intersex specimens have been reported in several marine fish (Devlin \& Nagahama 2002; Bahamonde et al. 2013).

Phenotypic sex lability is a characteristic of most fish species, and sex override can happen under the influence of sex steroids during the gonad differentiation (Yamamoto 1969; Devlin \& Nagahama 2002). An endocrine disruption possibly occurred in the first specimen of the Antarctic toothfish, leading to the bisexual development of its gonads.

A filiform shape generally characterizes abnormal gonads in old/large fishes with no signs of gonad development. This type of gonads has been described in both sexes of several species, such as polar cod (Boreogadus saida [Lepechin, 1774]), common carp (Cyprinus carpio Linnaeus, 1758) and walleye pollock (Theragra chalcogramma [Pallas, 1814]) (Khristoforov 1975; Manzoor Ali \& Satyanarayana Rao 1989; Zhukova \& Ponomarev 2016).

Both the external morphology and the histological analysis indicated significant differences between this filiform gonad and normally developing immature gonads. The unusual massive growth of the connective tissue and low number of germ cells may be signs of age-specific changes or senescence, as reported in some representatives of Gadidae (Khristoforov 1975; Zhukova \& Ponomarev 2016) and Clupeidae (Mikodina et al. 2005).
Our study extends the understanding of the Antarctic toothfish sexual development, documenting the possibility of long-term interruptions in the reproductive cycle of this species.

\section{Acknowledgements}

The authors wish to thank Yury A. Mitenkov (Russian Research Institute of Fisheries and Oceanography) for sampling and Dr Natalia V. Belova (Lomonosov Moscow State University) for help in histological sections interpretation.

\section{Disclosure statement}

No potential conflict of interest was reported by the authors.

\section{Funding}

The work was supported by the Russian Science Foundation (grant no. 17-74-10203).

\section{ORCID}

Kristina A. Zhukova (D) http://orcid.org/0000-0001-8088435X

Ilya I. Gordeev (iD http://orcid.org/0000-0002-6650-9120

Elena N. Kuznetsova (D) http://orcid.org/0000-0001-80224116

\section{References}

Atz J.W. 1964. Intersexuality in fishes. In C.N. Armstrong \& A. J. Marshall (eds.): Intersexuality in vertebrates including man. Pp. 145-232. London: Academic Press.

Bahamonde P.A., Munkittrick K.R. \& Martyniuk C.J. 2013. Intersex in teleost fish: are we distinguishing endocrine disruption from natural phenomena? General and Comparative Endocrinology 192, 25-35.

Brown-Peterson N.J., Wyanski D.M., Saborido-Rey F., Macewicz B.J. \& Lowerre-Barbieri S.K. 2011. A standardized terminology for describing reproductive development in fishes. Marine and Coastal Fisheries 3, 52-70.

Calvo J., Morriconi E., Rae G.A. \& San Roman N.A. 1992. Evidence of protandry in a Subantarctic notothenid, Eleginops maclovinus (Cuv. \& Val., 1830) from the Beagle Channel, Argentina. Journal of Fish Biology 40, 157-164.

CCAMLR 2011. Scientific observers manual (observation guidelines and reference materials). Hobart: Commission for the Conservation of Antarctic Marine Living Resources.

Devlin R.H. \& Nagahama Y. 2002. Sex determination and sex differentiation in fish: an overview of genetic, physiological, and environmental influences. Aquaculture 208, 191-364.

Dunn A., Hanchet S.M. \& Ballara S. 2007. An updated descriptive analysis of the toothfish (Dissostichus spp.) tagging program in Subareas 88.1 and 88.2 for 2006/07. Paper presented at the Working Group on Statistics, Assessments and Modelling of CCAMLR as document WG-SAM-07/5, 09-13 July, Hobart, Australia.

Eastman J.T. \& DeVries A.L. 2000. Aspects of body size and gonadal histology in the Antarctic toothfish, 
Dissostichus mawsoni, from McMurdo Sound, Antarctica. Polar Biology 23, 189-195.

Everson I. \& Murray A. 1999. Size at sexual maturity of Patagonian toothfish. CCAMLR Science 6, 37-46.

Fenaughty J.M. 2006. Geographical differences in the condition, reproductive development, sex ratio and length distribution of Antarctic toothfish (Dissostichus mawsoni) from the Ross Sea, Antarctica (CCAMLR Subarea 88.1). CCAMLR Science 13, 27-45.

Ghigliotti L., Cheng C.H.C. \& Pisano E. 2016. Sex determination in Antarctic notothenioid fish: chromosomal clues and evolutionary hypotheses. Polar Biology 39, 11-22.

Hanchet S., Dunn A., Parker S., Horn P., Stevens D. \& Mormede S. 2015. The Antarctic toothfish (Dissostichus mawsoni): biology, ecology, and life history in the Ross Sea region. Hydrobiologia 761, 397-414.

Hanchet S.M., Rickard G.J., Fenaughty J.M., Dunn A. \& Williams M.J. 2008. A hypothetical life cycle for Antarctic toothfish (Dissostichus mawsoni) in the Ross Sea region. CCAMLR Science 15, 35-53.

Hunter J.R. \& Macewicz B.J. 1985. Rates of atresia in the ovary of captive and wild northern anchovy, Engraulis mordax. Fishery Bulletin 83, 119-136.

Khristoforov O.L. 1975. Izmenenija v sostojanii gonad i gipofiza sajki, Boreogadus saida Lep., svjazannye so stareniem. (Changes in the condition of gonads and hypophysis of Arctic cod Boreogadus saida Lep., related to aging.) Trudy VNIRO 111, 160-171.

Kuznetsova E.N., Petrov A.F. \& Bizikov V.A. 2012. Method of age determination for Antarctic toothfish (Dissostichus mawsoni). Paper presented at the Working Group on Statistics, Assessments and Modelling of CCAMLR as document WG-SAM 12/18, 25-29 June, Santa Cruz de Tenerife, Spain.

Livingston M.E. \& Grimes P. 2005. Size at maturity and histological procedures explored to determine spawning activity of female Dissostichus mawsoni from samples collected from the Ross Sea in January 2004, December 2004 and January 2005. Paper presented at the Working Group on Fish Stock Assessment of CCAMLR as document WG-FSA-05/63, 8-19 October, Hobart, Australia.

Manzoor Ali P.K.M. \& Satyanarayana Rao G.P. 1989. Growth improvement in carp, Cyprinus carpio (Linnaeus), sterilized with 17a-methyltestosterone. Aquaculture 76, 157-167.

McBride R.S., Somarakis S., Fitzhugh G.R., Albert A., Yaragina N.A., Wuenschel M.J., Alonso-Fernandez A. \& Basilone G. 2015. Energy acquisition and allocation to egg production in relation to fish reproductive strategies. Fish and Fisheries 16, 23-57.

Mikodina E.V., Sedova M.A. \& Smirnov A.A. 2005. On abnormal gonads of the Gizhiga-Kamchatka population of the herring Clupea pallasi (Clupeidae). Journal of Ichthyology 45, 191-199.

Mugue N.S., Petrov A.F., Zelenina D.A., Gordeev I.I. \& Sergeev A.A. 2014. Low genetic diversity and temporal stability in the Antarctic toothfish (Dissostichus mawsoni) from near-continental seas of Antarctica. CCAMLR Science 21, 1-9.

Parker S.J. \& Grimes P.J. 2010. Length- and age-at-spawning of Antarctic toothfish (Dissostichus mawsoni) in the Ross Sea. CCAMLR Science 17, 53-74.

Petrov A.F., Shust K.V. \& Gordeev I.I. 2014. Assessment of fishing capacity of Antarctic toothfish Dissostichus mawsoni, the Weddell Sea based on the results of longline survey 2013. Problems of Fisheries 15, 320-328.

Piyanova S.V. 2008. Some data on the reproductive system condition of Antarctic toothfish (Dissostichus mawsoni) males and females from the Indian Ocean area in summer. Paper presented at the ICES Annual Science Conference as document ICES CM 2008/C:09, 22-26 September, Halifax, Canada.

Piyanova S.V. \& Kokorin N.V. 2010. Cytomorphology of female and male gonads in Antarctic toothfish Dissosctichus mawsoni (Nototheniidae) from the Ross Sea in the summer period. Journal of Ichthyology 50, 374-385.

Piyanova S.V. \& Petrov A.F. 2009. The histological analysis of oogenesis and maturity of Antarctic toothfish from the Ross Sea. Paper presented at the Working Group on Fish Stock Assessment of CCAMLR as document WGFSA-09/26, 12-23 October, Hobart, Australia.

Prutko V.G. \& Lisovenko L.A. 2005. New data on Antarctic toothfish and some others by-catch fishes fecundity with gonads histological pictures from Ross Sea region and data on Patagonian toothfish from the Argentina sea. Paper presented at the Working Group on Fish Stock Assessment of CCAMLR as document WG-FSA-05/28, 8-19 October, Hobart, Australia.

Rideout R.M., Rose G.A. \& Burton M.P.M. 2005. Skipped spawning in female iteroparous fishes. Fish and Fisheries 6, 50-72.

Sadovy Y. \& Shapiro D.Y. 1987. Criteria for the diagnosis of hermaphroditism in fishes. Copeia 1, 136-156.

Yamamoto T. 1969. Sex differentiation. In W.S. Hoar \& D. J. Randall (eds.): Fish physiology. Vol. 3A. Pp. 117-175. New York: Academic Press.

Yukhov V.L. 1982. Antarktičeskij klykač. (Antarctic toothfish.) Moscow: Nauka.

Zhukova K.A. \& Ponomarev S.S. 2016. Study of the filiform gonads of walleye pollock Theragra chalcogramma inhabiting the Sea of Okhotsk and the Bering Sea. Journal of Ichthyology 56, 752-759. 